BEYOND MAXIMUS 



\section{BEYOND MAXIMUS}

The Construction of Public Voice

in Black Mountain Poetry

Anne Day Dewey

STANFORD UNIVERSITY PRESS

STANFORD, CALIFORNIA

2007 
Stanford University Press

Stanford, California

(C) 2007 by the Board of Trustees of the Leland Stanford Junior University. All rights reserved.

No part of this book may be reproduced or transmitted in any form or by any means, electronic or mechanical, including photocopying and recording, or in any information storage or retrieval system without the prior written permission of Stanford University Press.

Printed in the United States of America

on acid-free, archival-quality paper

Library of Congress Cataloging-in-Publication Data

Dewey, Anne Day.

Beyond Maximus: the construction of public voice in Black Mountain poetry / Anne Day Dewey.

$$
\text { p. } \mathrm{cm} \text {. }
$$

Includes bibliographical references and index.

ISBN 978-0-8047-5647-I (cloth : acid-free paper)

I. American poetry-North Carolina-Black Mountain-History and criticism. 2. American poetry—2oth century—History and criticism. 3. Black Mountain school (Group of poets) 4. Poets, American—2oth century-Political and social views. 5. Politics and literature-United States-History-2oth century. 6. Black Mountain (N.C.) - Intellectual life. I. Title.

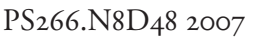

$8 \mathrm{II} \cdot .54099756-\mathrm{dc} 22$ 2006100990

Typeset by Westchester Book Group in II/13.5 Garamond 
For my mother and in memory of my father 
